\title{
ВЛИЯНИЕ ВНЕДРЕНИЯ БИОМЕТРИИ В АЭРОПОРТАХ НА ИНФОРМАЦИОННО-ПСИХОЛОГИЧЕСКУЮ БЕЗОПАСНОСТЬ ЛИЧНОСТИ
}

\author{
Максина Марина Сергеевна \\ Аспирант, Российский университет транспорта \\ (МИИТ) \\ marina.maxina2016@yandex.ru
}

\section{THE IMPACT OF THE INTRODUCTION OF BIOMETRICS IN AIRPORTS ON THE INFORMATION AND PSYCHOLOGICAL SECURITY OF THE INDIVIDUAL}

\section{Maksina}

Summary. The article is devoted to the problems of information and psychological protection of the individual in the implementation of biometric systems at airports. The article analyzes modern approaches to the study of legal aspects of information and psychological security of the individual in transport. It is emphasized that modern information technologies have a great influence on people's consciousness and their psyche. The introduction of a Unified biometric System at airports implies an even greater urgency of the issues of legal support for information and psychological security of the individual in transport.

Keywords: information and psychological security of the individual; unified biometric system, ensuring information security; implementation; information and psychological threat to the individual.
D опубликованной программе цифровой трансформации Минтранса, говорится о том, что к концу 2023 года $6 \%$ российских аэропортов должны будут использовать для идентификации пассажиров биометрию, а для обработки данных - искусственный интеллект, все это нужно для того, чтобы упростить транспортные процедуры. Также если министерство найдет дополнительные источники финансирования, дабы реализовать так называемый сценарий развития, то процент аэропортов с такими системами должен увеличится до 15.

Как известно, понятие информационно-психологической безопасности подразумевает состояние защищенности отдельных лиц, групп лиц от негативных информационно-психологических воздействий и связанных с этим иных жизненно важных интересов личности,
Аннотация. Статья посвящена проблемам информационно-психологической защиты личности при внедрении биометрических систем в аэропортах. В статье проводится анализ современных подходов к изучению правовых аспектов информационно-психологической безопасности личности на транспорте. Выделено, что большое влияние на сознание людей и их психику оказывают современные информационные технологии. Внедрение биометрических систем в российских аэропортах рассматривается в качестве новых угроз на информационно-психологическую безопасность личности, что обуславливает актуальность поиска новых способов противодействия информационно-психологическому, деструктивному воздействию на личность. Из этого следует что, в процессе масштабного внедрения биометрической идентификации при прохождении предполетных процедур, должен учитываться фактор информационно-психологической защиты личности в качестве одного из приоритетных. Решение организационно-правовых проблем при внедрении биометрии должно сопутствовать созданию эффективного механизма обеспечения информационной безопасности. Внедрение Единой биометрической системы в аэропортах предполагает еще большую актуальность вопросов правового обеспечения информационно-психологической безопасности личности на транспорте.

Ключевые слова: информационно-психологическая безопасность личности; единая биометрическая система, обеспечение информационной безопасности; внедрение; информационно-психологическая угроза личности.

общества и государства в информационной сфере. Внедряемая система обуславливает проявления негативных информационно-психологических воздействий на значительную часть пассажиров. В ходе опроса аналитического центра НАФИ выяснилось, что ровно половина россиян не поддерживают создание российской Единой биометрической системы. Центром было опрошено около 1,6 тысячи человек в 53 регионах России.

Единая биометрическая система (ЕБС) работает в нашей стране с 2018 года. Система подразумевает возможность загрузить фото своего лица и запись голоса, чтобы с их помощью вместо паспорта подтверждать личность для получения цифровых услуг. Оператором системы является «Ростелеком». Изначально с помощью ЕБС можно было открывать счета, вклады и получать кредиты, в 2019 году в тестовом режиме ее начали применять 
при проведении экзаменов в Уральском федеральном университете им. Б.Н. Ельцина, для оплаты в сети кофеен Coffee Bean и др. В декабре 2020 года президент России Владимир Путин подписал закон о расширении использования ЕБС, с ее помощью можно будет дистанционно заключать договоры на оказание услуг связи, участвовать в судебных заседаниях и др. Для использования новой системы, гражданину России нужно будет сдать данные в ЕБС в одном из отделений банков, а также дать согласие на использование биометрии в конкретных целях.

О таких новшествах столичные аэропорты задумались еще в 2019 году. Тогда Домодедово объявило о внедрении автоматизированных турникетов (eGate) на выходах на посадку. Пассажиры получили возможность самостоятельно сканировать 2D-штрих-код и QR-код на бумажном или электронном носителе для прохождения в международную галерею вылета или на борт воздушного судна. В феврале 2020 года аэропорт анонсировал внедрение контроля пассажиров по биометрии лица уже в 2021 году, рассказывал тогда представитель Домодедово. С конца 2019 года тестирование кабинок идентификации личности по биометрии при пересечении границы началось в Шереметьево [2].

В связи с эпидемиологической ситуацией в стране, была разрешена самостоятельная сдача биометрии в Единую биометрическую систему. Такое нововведение не отстраняет возможности вмешательства в систему мошенников, что естественно представляет угрозу как информационно-психологической безопасности, так и безопасности личности в целом.

Соответствующий законопроект был внесен на рассмотрение в госдуме в конце апреля 2020 года. Этот законопроект наделяет одинаковым правовым статусом биометрические данные, собранные как кредитными организациями, так и самостоятельно физическими лицами [2]. Соответственно, этой уязвимостью могут воспользоваться различные мошенники. Например, если телефон жертвы попадет в руки злоумышленников, они могут разместить в ЕБС свои голос и лицо, а остальные данные внести от имени потерпевшего. В результате чего, преступники могут взять кредит в банке или спокойно проходить транспортные процедуры не под своим именем.

Участники рынка предлагают внести в законопроект следующие поправки:

- Сообщать кредитной организации, каким образом были предоставлены биометрические данные - самостоятельно, в отделении банка, МФЦ и т.п.

- Если биометрия сдана самостоятельно, то банки должны получить право проводить дополни- тельную проверку клиента с помощью видеосвязи и отказывать в обслуживании, если считают, что это не тот, кто сдавал биометрию.

- Установить ответственность физических лиц за достоверность биометрических персональных данных, размещаемых ими в ЕБС. Она может быть как административная, так и уголовная в зависимости от тяжести последствий.

- Разработать механизм корректировки биометрических персональных данных в случае выявления их недостоверного или ошибочного внесения в ЕБС, физическим лицом.

Совместно с предложениями по улучшению законопроекта о биометрии НСФР направил в Госдуму и другие органы власти свой законопроект об организации проверки личности с использованием системы видеосвязи, который предлагает рассмотреть параллельно [3].

С 1 января 2021 года вступил в силу закон об использовании Единой биометрической системы (ЕБС) для удаленной идентификации при получении финансовых и государственных услуг. Ранее собирать биометрические данные могли организации с базовой лицензией, этот закон предоставляет таким организациям право, а не обязанность, собирать биометрические данные в ЕБС. А организации с универсальной лицензией будут обязаны предоставить физическим лицам возможность открывать счета и оформлять рублевые кредиты без личного присутствия (после проведения идентификации клиента). Организации смогут размещать сведения о клиенте в единой биометрической системе только с его согласия и на безвозмездной для него основе [3].

То есть для использования технологий оператор аэропорта должен будет заключать соглашение об информационном взаимодействии с оператором Единой государственной информационной системы обеспечения транспортной безопасности (ЕГИС ОТБ).

Применение технологии искусственного интеллекта, то есть возможность использования биометрии вместо посадочного талона, невозможно без изменений нормативно-правовых актов. Для идентификации пассажиров с помощью биометрии, аэропорт должен обеспечить защиту персональных данных, а также информационную безопасность.

Использование защищенных биометрических методов идентификации личности, приведет к наиболее надежной защите информационной безопасности личности. Некоторые из биометрических систем имею способность определять личность бесконтактным способом, что особо актуально в условиях пандемии. 
В зарубежных аэропортах уже используются различные инновационные методы, для ускорения регистрации пассажиров на рейс.

В заключение можно сказать, что состояние транспортной безопасности в целом затрагивает фундаментальные интересы личности, особенно в условиях пандемии. В ходе проведенного анализа определены некоторые противоречия, пробелы законодательства и правоприменительной практики, имеющие существенное теоретическое и практическое значение для обеспечения законности на транспорте в условиях угрозы распространения коронавирусной инфекции.

\section{ЛИТЕРАТУРА}

1. Авиакомпании впишут в дигитальный паспорт пассажира информацию о сделанной прививке // Московский комсомолец. Ру.- Режим доступа: https://www.mknews.de/social/2020/12/21/aviakompanii-vpishut-v-digitalnyy-pasport-passazhira-informaciyu-0-sdelannoy-privivke.html (дата обращения 30.11.2020).

2. Минтранс предложил массово внедрять биометрию в аэропортах// РБК — режим доступа:

3. https://www.rbc.ru/technology_and_media/17/02/2021/602a97209a7947d41f3ef011 (дата обращения 30.01.2021).

4. Половина россиян не поддержали создание властями биометрической системы// Подробнее на РБК — режим доступа https://www.rbc.ru/technology_ and_media/28/12/2020/5fe5cee59a7947dfd4362d12 (дата обращения 30.01.2021)

5. Федеральный закон от 27.07.2006 N152-Ф3 (ред. от 30.12.2020) «0 персональных данных»

6. Проект Федерального закона № 99114515-2 «0б информационно-психологической безопасности» (ред., внесенная в ГД ФС РФ, текст по состоянию на 03.12.1999).

7. Чеботарева А.А. «Правовое обеспечение информационной безопасности личности в глобальном информационном обществе» дис. док.юр.наук: 12.00.13.M., 2018. $-473 \mathrm{c}$.

() Максина Марина Сергеевна ( marina.maxina2016@yandex.ru ).

Журнал «Современная наука: актуальные проблемы теории и практики»

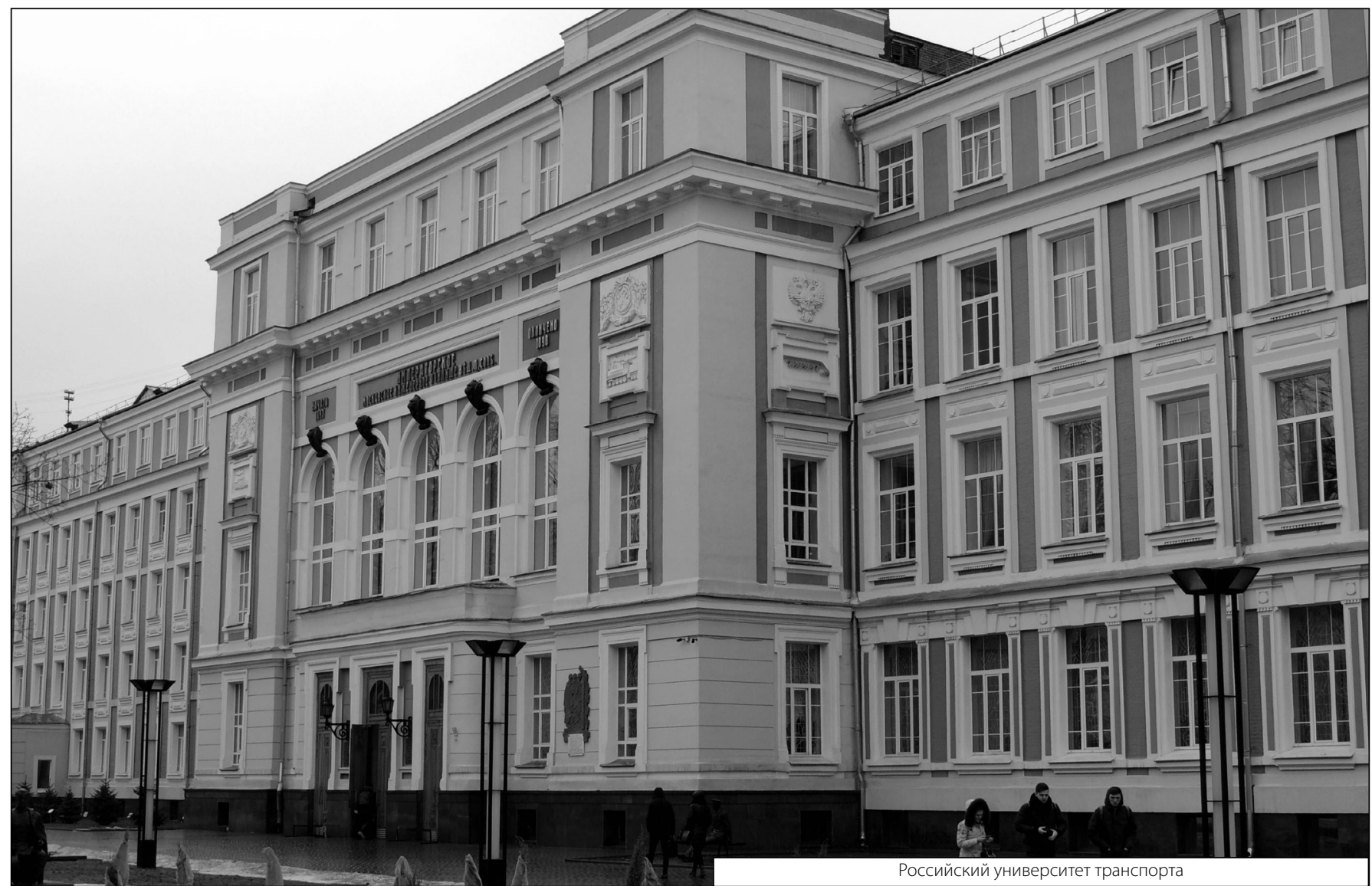

